\author{
Noemi Bravená* \\ Charles University in Prague, Czech Republic
}

\title{
Today's Czech Family and Care for Child's Transcendence
}

\section{Introduction}

Since the Velvet Revolution in 1989, in the Czech Republic we are experiencing significant changes, concerning every person and their faith ${ }^{1}$. A recent document of the Plenary Assembly of the Catholic Church in the Czech Republic, The Life and Mission of Christians in the Church and in the World ${ }^{2}$, refers to recent problems concerning the family. The document presents families across social and politicalhistorical contexts, while pointing to the seriousness of the issue, i.e. the problem of the family in the Czech society in the 21 st century. Therefore, we will focus on

* NOEMI BRAVENÁ lectures at the Hussite and Catholic theological faculties of Charles University in Prague. At present she is writing a Ph.D. thesis for primary pedagogy at the Faculty of Education of the same University. In 2003-2006 she was assistant professor of Biblical Theology and in 2009 she defended a Th.D. thesis about substitution conception in Dietrich Bonhoeffer's theology. Since 2006 she is assistant professor of Practical Theology. Her professional focus is pedagogy, religious education, catechetics, hermeneutic of children, pastoral care, New Testament.

1 This part of the monograph was written as part of research projects of the Charles University in Prague: PRVOUK 01 “Theology as a way of interpreting history and culture” and GAUK nr. 330411: "Transcendence and its meaning for the socialization and formation process of child's personality", also supported by the grant of John Huss Foundation in the Czech Republic.

2 Život a poslání krestanů v církvi a ve světě. Závěrečný dokument Plenárního sněmu katolické církve v ČR. Praha 2007, ČBK, art. 266-273. 
a broader context first, where family values, attitudes towardsoneself and others, and faith in transcendent reality are being shaped.

\section{The main characteristics of today's Czech family}

Each family is unique; however, it is possible to identify some characteristic features which result from Czech national history and culture.

\subsection{Ideological orientation}

After 1950, the population in the Czech Republic was divided mostly between Christians and atheists. Marxist political ideology forced opposition between the two. If one family member was a Christian he had problems with other family members. It frequently happened that the father had given information against his own son to the state police: that his son was a Christian believer and attended the Church. As a result he was unable to study at college, to get a good job and this influenced his lifelong social status. Even today, there are many Czech families, whose relationships are damaged by the communist past, as seen in statements such as the following: "My brother is sick with us because we are Christians". "My grandpa does not understand me, because he is a believer". "I cannot talk with the family, because they have always been atheists" etc.

Since 1989, other world religions and sects have appeared in the Czech Republic. After nearly 40 years of hearing assertions about the harmfulness of religion, including Christianity, after the Velvet Revolution, new spiritual movements were accepted as something more attractive and modern than Christianity. Therefore, today's Czech society cannot be considered to be either completely atheistic, or non-religious, although it describes itself as being nonreligious and, some say. Atheistic ${ }^{3}$. Many people do not reject spirituality in general. Czech psychologist of religion, Pavel Říčan, talks about a world phenomenon, which has taken root within

3 Religious educationist Muchová describes the relationship of Czech secondary school students to religion in terms of their perceptions of religion as an institution. Muchovás analysis of 70 student essays from 2009 concludes that, for these students, atheism is the predominant worldview. Their testimonies contain "simple, often one-sided and uninformed or ill-informed ... arguments in favor of their own atheism and in the detriment of the Christian faith or no religion as such". See more in L. Muchová, Budete mými svědky, p. 74-75, 77. 
the Czech Republic as well: this is expressed by the motto "I am not religious, but I am spiritual"4. Some Czech research confirms this tendency among university students also ${ }^{5}$.

Many Czechs, in personal interviews, admit supra-religious spirituality, but they do not associate it with any institutional form. It is characterized by statements such as: "I know that there is something greater than us", "Man was given a higher task and mission on Earth", "I know that there is something greater than us", "Man was put on the earth due to a higher task or mission". It is a personal spirituality often connected with a positive view of life, prosocial behaviour, solidarity, ecology, wellness, etc., but not with religious faith within organized religion.

\subsection{Political situation}

Czechs are rather pessimistic. This is seen in the stereotype that the "true Czech" often complains about everything and is never satisfied with anything. This pessimistic attitude deepens the present political climate in the Czech Republic. The negative view of politics is influenced by the election deadlock, or the connection of some politicians with asset stripping ("tunneling") and various corruption cases. In one of my research studies a 10-year-old girl said, "Politicians want only money", which reflects the opinion of most Czech families. Many do not vote and those who vote, vote according to the principle: "Choose the lesser evil".

The political situation has an influence on the concept of family and marriage as well. Young families are not favoured by state politics, thus for a couple with children it is financially more advantageous not to get married.

\subsection{Fairy-tale cult}

Culture is the expression of the nation and contains treasured values for the next generations. The fairy tale is one example of Czech treasured culture. Televised fairy tales are enjoyed by many all year round, and it is hard to imagine life without them, especially at Christmas with the favourites: Cinderella, Goldilocks, Angel of the Lord, etc. The Czech family wants to protect its own tradition, which is deeply

\footnotetext{
4 P. Říčan, Psychologie náboženství a spirituality, Praha 2007, Portál, p. 11.

5 P. Říčan, P. Janošová, Spirituality as a Basic Aspect of Personality: A Cross-Cultural Verification of Piedmont's Model, "The International Journal for the Psychology of Religion" 20:2-13, London 2010, Routledge.
} 
influenced by the new Christmas figures such as reindeer, Santa Claus, Christmas dwarfs, etc. after the Velvet Revolution. These characters have already become part of the concept of Czech Christmas, especially in children's eyes. Parents try to maintain Czech Christmas tradition through the typical Czech habits, fairy tales and symbols, including the idea that Christmas presents are brought to them by the Child Jesus.

My research shows that the children of non-Christian families often portray the figure of the Child Jesus as Santa Claus, probably as a result of the influence of foreign Christmas movies for children and Christmas decorations in the stores. Children in Christian families are drawing the Child Jesus as a baby in the crib, sometimes they presents eventually an adult man hanging on the cross. They learned that this Christmas child is God, who was born to save man. That is why children do not have a problem to see Jesus as a baby and also as an adult man. The reader may ask himself 'Why such a diverse representation of the Jesus Child?' In the Czech tradition the gift-giving figure is invisible, so this fact opens space for the Christian mystery and also for another interpretation (Santa Claus) ${ }^{6}$. From the age of 8 years, believing children are able to distinguish the invisible fairy tale figure of Jesus Child (in Czech: Ježišek) and the Christian Child Jesus (in Czech: malý Ježís Kristus). One small boy told me: "the first one is only a fairy tale figure and brings gifts, but the baby Jesus lying in the crib is real and loves us".

In fairy tales, the victory of good over evil is a predominant theme. This perception provides a counterpart to the strong material and individualistic orientation of contemporary Czech society. Fairy-tales are often framed in terms of values and a higher meaning of life, and include figures of angels and the Christian Christmas story.

\subsection{Social status}

The Czech family today attaches more importance to social status than prior to 1989. In communist times, the majority had similar material things of daily use as well as similar job and travel opportunities. The situation is different today. Importance is attached to matters of gender, minorities, education and lifelong

6 See N. Bravená, Philosophizing with Children on National Tradition Related to Christmas, in: F. Kraft, H. Roose, G. Büttner (eds.), Symetrical communication? Philosophy and Theology in Classrooms across Europe, Loccum 2011, RPI, p. 61-74. 
learning, professional prestige and club or group membership, following the latest trends in society, etc.

The economic situation of a family plays a significant role. Children are mocked by their classmates if they do not own designer clothes, a cellular phone or expensive toys. In addition to this more and more families are living on the edge of a living wage and are regularly running into debt in order to keep their position within the society. There are also an increasing number of families who are not able to pay housing costs". The fact that many Czech men are "handymen" and are able to produce furniture, make repairs of household items and reconstructions of the flat helps to maintain a certain standard for some families.

The increased importance of social status is due to the state of the Czech economy and employment, as well as the concept of materialism as a new life orientation. The modern and cool individual is someone who confesses to this new "religion". Those who do not may be stigmatized and separated from society.

\subsection{Leisure time}

Most Czech families enjoy traveling and spending time in their weekend cottages. Closeness to nature and peace are sought, including a passion for collecting mushrooms which some people designate as the Czech national sport. Canoeing and skiing, which are supported by families and schools, are also popular.

Very often we hear the phrase: "I did not catch anything", referring to a time deficit experienced by many people. Part of the problem is the inability to distinguish between relevant and irrelevant matters of life. However, the economic situation in the Czech Republic is also to blame, forcing families to make work and the financial security of the family the main priority. For this reason, some people have a second job. Many people in the Czech Republic are more occupied at their work due to the increase of administration and wage economies. Finances and time prevent families from spending more time together and participating in culture, new books and other leisure activities.

\footnotetext{
7 See the theme of the International Day for the Eradication of Poverty http://www.armadaspasy.cz/ praha/narodni-ustredi/rodiny-ohrozene-chudobou-jsou-v-ceske-republice-na-vzestupu (17.10.2014).
} 


\subsection{View on marriage}

Before 1989, relationships in Czech families were closer. The question is, what led to this closeness? On the one hand, people were more able to appreciate nice things and the importance of relationships. On the other hand, there were many couples remaining together because of children or their housing situation.

After the revolution, the divorce rate and number of unmarried couples has increased ${ }^{8}$. There is a frequent tendency of "living together on trial". Young people's answers are mostly the same: "Why marry? It is only a sheet of paper", "If we find out that we are not compatible, we break up without divorce". The problem is also described in the above-mentioned document of the Plenary Assembly of the Catholic Church in the Czech Republic, where we can read that: "It is one of the consequences of great demands on quality of the marital relationship and the widespread erroneous assumption that success of the relationship depends completely on the successful choice of the partner".

The problem is extended by "a skeptical attitude" of media and overestimation of "prestigious consumption" ${ }^{10}$. Many couples are discouraged from starting a family or are forced to delay it until, as they say, "they can afford it".

If a young person does not have a positive view of marriage formed by a specific value orientation or religious faith, he/she does not consider getting married until a child is born.

\section{Child's transcendence}

Czech psychologist Zdeněk Helus includes human transcendence (outreach) in his theory of personality. Concerning this "quality of personality", everyone is differently developed and has other possibilities and dispositions ${ }^{11}$. A functioning family and a sensible mother-child relationahip is fundamental for the development

8 For divorce rate see population census and data of the Czech Statistical Office: http://www. czso.cz/csu/2013edicniplan.nsf/p/4032-13.

9 Život a poslání křestanů v církvi a ve světě.art. 267, NB 172, p. 86.

10 Život a poslání krestanů v církvi a ve světě. art. 267-268, p. 86.

${ }_{11}$ Z. Helus, Ditě v osobnostním pojetí: Obrat $k$ ditěti jako výzva a úkol pro učitele i rodiče, Praha 2009, Portál, p. 104. 
of human transcendence. This is the basis for all future relationships ${ }^{12}$. The concept of transcendence in his psychology does not relate to God primarily, but it refers to the human capacity to live and relate without egocentrism.

Children's transcendence can be defined according to vertical and horizontal directions of the non-egocentric thinking related to the child's conscious activity - insight, faith, inner belief, emotions, feelings of hope, attitudes and mutuality etc.

The vertical direction is connected with abstract concepts - God, cosmos or a higher sense. A child's relationship to these can be developed through religious and philosophic education. The horizontal direction includes concrete concepts, such as the relationships in the family, relationship with oneself, with classmates, with other people, with nature, to state etc. The horizontal direction is especially developed through cultivating personality, ethics, multicultural education and cross-curricular topics (e.g. health care). This means that both horizontal and vertical directions should be an inseparable part of the child's upbringing and education. It follows that religious education has an irreplaceable function in developing care for transcendence as a part of a child's personality, which is, up till now, not quite evident within the Czech Republic.

\section{Possibilities of a child's developing transcendence,}

In this part, I will present particular characteristics of the Czech family which were described in the first chapter and mention some possibilities to help a child's developing transcendence in Czech schools, and in secular and Christian families.

\subsection{Care for child's transcendence (outreach) ${ }^{13}$ and world view}

Children should be encouraged to understand from an early age the concepts of understanding, listening and giving reasons for their own assertions. This idea is supported in modern pedagogy in the concept of development of critical thinking. For this reason, some Czech schools include such a method in their programme: "Reading and Writing for Critical Thinking" (RWCT). Personalised educational methods can be used as well as for philosophical and religious topics. Such topics cannot be found in Czech educational materials of RWCT: for example, I usually

12 P. Ríčan, Psychologie náboženství a spirituality, Praha 2007, Portál, p. 240.

13 The author refers to therminology used in theology and in „psychology of outreach“. 
include, in my teaching, a method called "cubing" (Cowan and Cowan, 1980) ${ }^{14}$ for religious and philosophic terms. I assume that RWCT methods can be used to cultivate not only critical thinking, i.e. another point of view, but also verbal formulations of ideas about particular religious terms.

Families have the potential to lead children to be open to different world views. The religious family leads its children to a deeper sense of faith in something which is beyond human. It means that religion opens for the child another meaning of the word 'transcendence' (outreach), which is not primarily an ability of humans, but represents a higher reality. The Christian family connects the term 'transcendence' with God and the uniqueness of God's love that led to sacrifice of His own Son for mankind and encourages true following lived by faith. The Christian family is being called to "Make the Resurrected Lord present in your whole life"15.

This is a contribution of the Christian family to Czech society, which means that its faith is not blinded by its own perfection, but open to questions and needs of others. This faith is consistent and loving at the same time. Czech pastoral theologian Aleš Opatrný underlines a missionary character of the family, saying, "People who live in families, recognize and appreciate the strength and power of the gospel in someone who lives in the same conditions rather than in somebody whose living conditions are totally different"16.

\subsection{Care for child's transcendence (outreach) and politics}

The text of the Framework Education Programme for Elementary Education (further on FEP EE) admits Civics from a sixth grade and Civic Education For Democracy as an obligatory teaching area, i.e. a cross-curricular subject ${ }^{17}$, which is a relatively new phenomenon and therefore means rather a challenge for the Czech school”'18.

14 J. L. Steelová, M. S. Kurtis, Ch. Temple, W. Scott, Čtením a psaním ke kritickému myšlení, in: N. Rutová, I. Věříšová, Př́ručka II: Rozvijíme kritické myšlení, Kritické myšlení o.s., Praha 2007, p. 27.

15 Život a poslání křestanů v církvi a ve světě, art. 222, p. 74.

16 A. Opatrný, Rodina dnes - Úvahy k májovým pobožnostem. http://knihovna.net/KNIHA/0056_t. htm.

$17 \quad$ FEP EE, p. 107.

18 See J. Stará, Výchova k demokratickému občanství, in: V. Spilková, Proměny primárního vzdělávání $v \check{C} R$, Praha 2005, Portál, p. 225. 
For this reason, every family should lead its children to their own responsibility from babyhood, taking them to elections and trying to have a positive outlook on politics, being open to political decisions, teaching them to love their country and be ready to support their state.

The Christian family should point to a different political dimension, i.e. Catholic families should acquaint their children with the Church's social teaching and "be interested in how the principles are respected in the programmes... and practice of political parties" 19 . Taking care of transcendence (outreach) in this area means: to lead children to understand and support those political parties that have Christian values, despite the fact that "Christians are a minority, which still has very little direct political influence" in the Czech Republic ${ }^{20}$. It is most important that Christians go to vote in elections and lead their children to follow their example. They also show their children that "politics is not merely a contest for power, but also a service to people; it is an art and occasion for brave, consistent, truthful and incorrupt people"21.

\subsection{Care for child's transcendence and fairy-tale stories}

Children should be shown that culture has many hidden and timeless components. Culture itself is human transcendence (outreach). It is not just a fairy tale, but it is "everything by which man cultivates and develops his psychic and physical abilities, what rules the Earth, humanizes social life and expresses his spiritual experiences and desires" 22 . Encouraging children toward transcendent activity means to lead them to discover and appreciate all areas of culture.

The school should provide more opportunities to debate the sense of fairy tales and instructive narrative stories in education, which means that teachers should lead children to a deeper understanding of the narrative texts. At Czech primary schools, "Czech language and literature" is a compulsory subject. Most teachers focus on the content of the text, but they are in danger of neglecting the hermeneutics.

Czech philosopher of education Radim Palouš in his book, Heretická škola (Heretic School), writes about the, so-called, "higher education". Besides the fact that such an education leads a child to wonder, it should also destroy foolishness.

19 Život a poslání křestanů v církvi a ve světě, art. 277, p. 90.

20 Život a poslání křestanů v církvi a ve světě, art. 283, p. 92.

${ }^{21}$ Pokoj a dobro. List ČBK k sociálním otázkám v České republice, art. 35, p. 37.

${ }^{22}$ Život a poslání křesṫanů v církvi a ve světě, art. 247, p. 79. 
This is the problem of modern humanity, which does not admit that a myth or fairy tale can speak of a human's situation and "his place in the world." It is a result of human dominance over nature rather than belonging to $i^{23}$. Leading children to the deeper meaning of fairy tales is a task both for schools and parents, especially because of the love Czechs have for these stories.

Christian parents should talk with their children: not only about the world and lessons of fairy tales, but also lead them to appreciate Christian literature and cinematography and talk also about films on moral topics in the light of Christian ethics. The Church document The Life and Mission of Christans in the Church and in the World clearly declares that "a key role of media for modern society has been undervalued in the Church for a long time"24. The document appeals for the media to be part of education, because it contributes to the orientation in the present world ${ }^{25}$. Why not connect to the deeper message of fairy tales, as people are most interested in them in the Czech Republic?

\subsection{Care for child's transcendence and social status}

Schools should lead children to accept others without prejudices, moving toward prosociality and solidarity. Bullying, which often targets persons of lower social status or disadvantaged pupils, should be discouraged. The concept of inclusive education, which is based on the pursuit of equal opportunities, is a good example for preparing conditions for the development of horizontal outreach of children. Another way is the focusing of schools on a complementary education field of The Framework Educational Programme for Basic Education called Moral Education. This area of education is considered optional subject and many schools do not include it in their curriculum at all. Because of this there is also a lack of philosophical discussions with children as well.

Every family should support a practical project in their surroundings. Many families, for example, sponsor poor children from a distance. By doing this, the family accepts people in need - that is the best way for children to learn. Children see in practice that parents are caring for them and also for others. The family may ensure a child's transcendence through any activity which shows a deeper

${ }^{23}$ R. Palouš, Z. Svobodová, Homo educandus: Filosofické základy teorie výchovy, Praha 2011, Karolinum, p. 25.

24 Život a poslání krestanů v církvi a ve světě, art. 307, p. 100.

25 Život a poslání krestảan v církvi a ve světě, art. 308, p. 101. 
dimension of humanity. I think that an excuse of many families is that they do not have money for practical helping projects. However, there are many activities that can be done for the benefit of others with minimal financial investment.

Besides charity projects, Christian families can support someone else in need in their surroundings or in their parish, not merely with money, but also by babysitting, shopping, coaching, mutual dialogue, prayer, searching for jobs for unemployed ${ }^{26}$ etc.

The future direction of believing families should be focused on "the common good" in the long term. The document The Life and Mission of Christians in the Church and in the World criticises short-sightedness and encourages support of everything that has a long-term "positive impact on families, children, youth, education, training and nature protection" ${ }^{27}$. To lead children to sensitivity to social status is giving hope that they will recognize the long-term perspective and want to focus their activities on it.

\subsection{Care for child's transcendence and a leisure time perspective}

Schools offer extracurricular activities that parents may make use of, or they may send their children to other voluntary activities. It is quite obvious that they participate in sports with their children, go to the cinema and theatre, go on trips, pick mushrooms etc. What is lacking are activities focused on philosophical talks, discussions about the life of a child, which means that nobody asks children's opinions, but everybody tells them how they should spend their free time. A good solution seems to be to focus on mutual deep dialogues about how to use leisure time.

Families should be aware of the value of leisure time and try to make the most of it for the family as a whole. After-school activities are not to be understood as a "depository" for children as some parents think, but should be a possibility of meeting and sharing for the whole family. Therefore, the state should also provide more support for such activities e.g. cheaper family tickets to different activities.

Christian families should include more parish and Church events in their leisure activities, because these activities contribute to the growth of the community. Not only prayer and catechesis, but also common trips of parishioners, voluntary work in church or common meals, contribute to the development of interpersonal relationships within the Church.

26 See Pokoj a dobro. List ČBK k sociálním otázkám v České republice, art. 38, p. 40.

27 Život a poslání křestanů v církvi a ve světě, art. 237, p. 77-78. 


\section{Conclusion}

The International Commission on Education formulated four pillars of education for the Twenty-first Century ${ }^{28}$. "Learning to live together" and "learning to be" are two of these pillars, which Czech society is beginning to discuss only now. These two pillars are fundamental for development of children's transcendence (outreach) including their faith in transcendence.

The school and family should lead children to activities that shape their relationship to others and "something higher" (God, meaning of life, responsibility toward future etc.).

The following summarizes contexts of care of children's transcendence (outreach):

1. World view (ideological) perspective: leading children to openness, authenticity, acceptance and understanding others; as well as to deeper meaning of human life including belief in God's existence;

2. Political life (civic) perspective: leading children to responsibility and patriotism, understanding the past and the present, seeing the good side of politics;

3. Fairy tale and myth perspective: leading children to discover imperatives and the timeless truth of humanity position in the world;

4. Social perspective: leading children to understand all people and to value other creatures, prosocial behaviour and solidarity in their immediate surroundings as well as interest in other human beings in the world;

5. Leisure activities perspective: leading children to another understanding of leisure time as coexistence with people sharing their own lives; it is not only relaxing of body and mind, but most of all the time to form oneself and one's own life opinion.

Families create and transmit values to children, teaching them about relationships between human beings and with God. The family is the place where children can experience a deeper meaning of life, a manifestation of faith, human love and the love of God at an early age.

In contemporary society, an often-heard comment from parents is "I do not have time": the cry of the postmodern individual pressed from all sides. This often means not having time for what is really important, such as focusing on the higher meaning of life, being together with others, loving each other. But in post-communist

28 J. Delors (ed.), Learning: The Treasure Within. Report to UNESCO of International Commission on Education for the Twenty-first Century. Unesco Publishing, 1996 [online]. 13/12/99, (09.06.2014). Available online http://www.unesco.org/delors/delors_e.pdf. 
Czech society, media, work, and social pressure provide a context in which people are able to manage only those things for which they wish to have time.

Taking care of children's horizontal and vertical transcendence (outreach) means to teach children a deeper view of life in the broadest possible context of society. For Christian laity it means to "permeate the world with the Christian spirit" and "to be witnesses to Christ in all circumstances within the midst of human society" 29 . This does not mean investing thousands of hours and lots of money, but living every minute as precious, enriching, formative, decisive for the future and given by God.

\section{Bibliography}

Bravená N., Philosophizing with Children on National Tradition Related to Christmas, in: F. Kraft, H. Roose, G. Büttner (eds.), Symetrical communication? Philosophy and Theology in Classrooms across Europe, Loccum 2011, RPI, p. 61-74.

Delors J. (ed.), Learning: The Treasure Within. Report to UNESCO of International Commission on Education for the Twenty-first Century. Unesco Publishing, 1996 [online]. 13/12/99, (09.06.2011). Available on WWW: http://www.unesco.org/delors/delors_e.pdf

Dokumenty II. Vatikánského koncilu, Praha 1995, Zvon.

Helus Z., Dítě v osobnostním pojetí: Obrat $k$ ditěti jako výzva a úkol pro učitele i rodiče, Praha 2009, Portál.

Muchová L., Budete mými svědky. Dialogické rozvijení křestanské identity ve světonázorové pluralitní společnosti - pedagogická výzva. Brno 2011, Kartuziánské nakladatelství a vydavatelství.

Opatrný A., Rodina dnes - Úvahy k májovým pobožnostem. http://knihovna.net/KNIHA/0056_t.htm.

Palouš R., Svobodová Z., Homo educandus: Filosofické základy teorie výchovy, Praha 2011, Karolinum.

Pokoj a dobro. List ČBK k sociálním otázkám v České republice.

Říčan P., Psychologie náboženství a spirituality, Praha 2007, Portál.

Ǩíčan P., Janošová P., Spirituality as a Basic Aspect of Personality: A Cross-Cultural Verification of Piedmont's Model, “The International Journal for the Psychology of Religion" 20:2-13, London 2010, Routledge.

Stala J., Familienkatechese in Polen um die Jahrhundertwende. Probleme und Herausforderungen, Tarnow 2008, Biblos.

29 Gaudium et Spes, in: Dokumenty II. Vatikánského koncilu, Praha 1995, Zvon, no. 43, p. 217-218. 
Stala J. and Osewska E., Sociological aspects of family religious education in Poland, in: E. Osewska, J. Stala (eds.), Religious Education/Catechesis in the Family. A European Perspective, Warszawa 2010, UKSW, p. 167-177.

Stará J., Výchova $k$ demokratickému občanství, in: V. Spilková, Proměny primárního vzdělávání $v \check{C} R$, Praha 2005, Portál, p. 225-243.

Steelová J. L., Kurtis M. S., Temple Ch., Scott W., Čtením a psaním ke kritickému myšlení, in: N. Rutová, I. Věríšová, Příručka II: Rozvijíme kritické myšlení, Kritické myšlení o.s., Praha 2007. Život a poslání křestanů v církvi a ve světě. Závěrečný dokument Plenárního sněmu katolické církve v ČR. Praha 2007, ČBK.

International Day for the Eradication of Poverty http://www.armadaspasy.cz/praha/narodni-ustredi/ rodiny-ohrozene-chudobou-jsou-v-ceske-republice-na-vzestupu (17.10.2014).

For divorce rate see population census and data of the Czech Statistical Office: http://www.czso. cz/csu/2013edicniplan.nsf/p/4032-13 (17.10.2014). 